\title{
CHAPTER 07: BACTERIA FROM BOVINE MASTITIS: SURVEY AND LITERATURE REVIEW
}

Patrícia Jacob dos Santos ${ }^{1}$; Silvia Leal Ladeira ${ }^{2}$; Helenice de Lima Gonzalez ${ }^{3}$; Giniani Carla Dors ${ }^{4}$; Patrícia da Silva Nascente ${ }^{5}$

\begin{abstract}
Subclinical bovine mastitis is the most prevalent and responsible for the loss of $70 \%$ in production, reducing milk secretion by $45 \%$. Clinical mastitis shows clinical signs, in addition to reducing production. The objective of this work was to study bovine mastitis in the literature and conduct research on bacteria in cases of mastitis in four dairy farms in the region of Pelotas - RS - Brazil. In addition to bibliographic research, pathogenic aerobic bacteria were isolated and identified in 94 milk samples with clinical mastitis ( $\mathrm{n}$ $=12)$ or subclinical $(n=82)$ with positive CMT $(+++)$. The samples collected and previously identified in test tubes were cultured in blood agar and oven $36^{\circ} \mathrm{C} / 24 \mathrm{~h}$, and reading the results performed within $24 \mathrm{~h}$ to $36^{\circ} \mathrm{C}$ aerobically. Bacterial growth was observed in $62(65.9 \%)$ samples: $12(19.4 \%)$ clinical mastitis and in $50(80.6 \%)$ subclinical mastitis. After identified biochemical characterization: Coagulase negative Staphylococcus sp. $(\mathrm{n}=29)$, Staphylococcus sp. Coagulase positive $(\mathrm{n}=6)$, Corynebacterium spp. $(\mathrm{n}=16)$, Streptococcus $\mathrm{spp} .(\mathrm{n}=7)$, Streptococcus uberis $(\mathrm{n}=4)$. The knowledge and identification of the etiological agent is important for the correct treatment and implementation of mastitis control and prevention methods and for herd monitoring.
\end{abstract}

Keywords: Mastitis, Card Mastitis Test, CMT, Somatic Cells Count, SCC.

\section{Introduction}

Milk is considered a complete food with high nutritional value, composed mainly of water $(87.3 \%)$, proteins (3.3 to $3.5 \%$ ), lipids (3.5 to $3.8 \%$ ), mineral salts $(0.7 \%)$, vitamins and lactose (4.9\%) (SGARBIERI, 2005). Being rich in proteins, vitamins, fats, carbohydrates and minerals is an important source of nutrients for humans and several bioactive compounds that are highly significant for several biochemical and physiological functions (MARTINS; ANDRADE, 2011; ORTEGA-ANAYA; JIMÉNEZ-FLORES, 2018; KHAN et al., 2019). And so, it can be better used by the body, it should be of excellent quality, thus ensuring efficiency (MENDONÇA et al., 1999). Milk and derivatives are excellent means for the development of desirable microorganisms, and other pathogenic and deteriorating microorganisms, as well as the milk microbiota has a direct influence on the health of bovine mammary glands, thus requiring care with their production: milking, processing and storage (GUIMARÃES; LANGONI, 2009; PANG et al., 2018). The microorganisms originate from the milk of infected udder, and the

\footnotetext{
${ }^{1}$ Programa de Pós Graduação em Bioquímica e Bioprospecção, UFPEL, patisfarma@gmail.com

${ }^{2}$ Faculdade de Veterinária, UFPEL, helenicegonzalez@ hotmail.com

${ }^{3}$ Faculdade de Veterinária, UFPEL, s.ladeira@hotmail.com

${ }^{4}$ Faculdade de Agronomia, UFPEL, dorsgi@yahoo.com.br

${ }^{5}$ Doutora, Instituto de BiologiaUFPEL, pattsn@gmail.com
} 
surface thereof or a variety of other sources environment (GODKIN; LESLIE, 1993; METZGER et al., 2018).

Mastitis is characterized by an inflammation of the mammary gland related to physical, chemical, thermal, or microbial, and $90 \%$ of mastitis are caused by bacteria (RAMALHO et al., 2012). This disorder can be classified as a form of presentation as clinical or subclinical (PHILPOT; NICKERSON, 1991). The clinical presentation is characterized by visible signs, while the subclinical form displays a degree of difficulty to identify because there is no clinical changes in the mammary gland that can be observed macroscopically (MIRA et al., 2013). A diagnosis of clinical mastitis is based on clinical observations with identification of the infectious agent. The subclinical form is usually the most prevalent accounting for approximately $70 \%$ of production losses may reduce the secretion of milk by $45 \%$ (FONSECA; SANTOS, 2000). In this case it is necessary to use other methods of diagnosis, somatic cell count (SCC) and somatic cell score (California Mastitis Test - CMT) are common diagnostic tests for the detection of subclinical mastitis (HARMON, 1994; MACHADO et al., 2000; DELLA LIBERA et al., 2011; ADKINS; MIDDLETON, 2018). In Brazil it can be said that subclinical mastitis is present in all dairy herds (MACHADO et al., 2000).

The pathogens involved in the etiology of bovine mastitis can be classified into "major" and "minor". The first category includes agents that cause higher SCC, significant changes in milk composition and, consequently, a great economic impact, the main ones being: Staphylococcus aureus, Streptococcus agalactiae, Coliforms, Streptococcus spp., Enterococcus spp., Pseudomonas spp., Actinomyces pyogenes and Serratia spp. Negative Coagulase (NC) Staphylococcus and Corynebacterium bovis pathogens are considered "minor" and promote moderate inflammation with lower SCC (HARMON 1994). Considering the source of infection, the agents of mastitis are classified, infectious (primary mastitis), such as: Streptococcus agalactiae, Staphylococcus aureus, Mycoplasma spp., Corynebacterium bovis, NC Staphylococcus, or environmental (secondary mastitis) such as Escherichia coli, Coliforms, Streptococcus uberis, Enterococcus spp., Streptococcus equinus (formerly S. bovis) and other environment Streptococcus spp. (COSTA et al. 1998, MENDONÇA et al. 1999; HEIKKILÄ et al., 2018).

The increase in somatic cells is the main feature used for the diagnosis of subclinical mastitis, other factors may however result in this change. There are several tests that assess Somatic Cell Count (SCC) of milk from these tests highlight the CMT, 
WMT (Wisconsin Mastitis Test) and Electronic Somatic Cell Count (SCC) (RUPP et al., 2000). The cultivation of milk samples from individual mammary quarters is used to identify an etiologic agent, especially in cases of positive CMT (BRAMLEY et al., 1996; SEARS et al., 1993). In times of automatization of dairy cow husbandry, objective tools for mastitis diagnostic are demand and moderns studies about diagnose show the true positives quarters on CATH ELISA or handheld dynamometer and an infrared thermometer to diagnose and score clinical and subclinical mastitis (MAHMMOD et al., 2013; WOLLOWSKI et al., 2019; PUGGIONI et al., 2020) but he results obtained in the investigation of the causal agents of mastitis are fundamental to the understanding of the specific problems of the herds, to guide rational measures to control mastitis and suggest changes regarding the management adopted, including performing susceptibility testing to indicate best medication for treatment (RADOSTITIS et al., 1994; BRAMLEY et al., 1996). The use of diagnostic tests indirectly leads to a reduction in mastitis cases, providing thus a higher quality milk product (MIRA et al., 2013).

The objective of this work was to study clinical and subclinical bovine mastitis in the literature and conduct research on bacteria frequency in cases of mastitis in four dairy farms in the region of Pelotas - RS - Brazil.

\section{Materials e Methods}

\section{Dairy Farm}

Four Jersey and Dutch dairy farms in Pelotas - RS were studied during the sixmonth period (January to June) to verify cases of clinical and subclinical mastitis (CMT $+++)$. The four farms milking was performed twice a day, with a mean interval of $12 \mathrm{~h}$. During visits was evaluate all lactating cows and the four mammary quarters.

The clinical mastitis was diagnosed by testing "Dark Background Test" with five first jets of milk and observation lumps. Subclinical mastitis was tested with California Mastitis Test (CMT). The test CMT is determined according to the degree of gelation or viscosity of the mixture of equal parts milk and reagent $(2 \mathrm{~mL})$ in the appropriate tray. The results may be negative or positive scores, the latter being classified in three levels $(+,++,+++)$. In this case were selected for the analysis process microbiological those with scores +++ , as well as cases of clinical mastitis with the presence of clinical signs.

\section{Milk Sampling}

After pre-dipping, "Dark Background Test" and CMT, from the mammary quarter 
positive to clinical or subclinical mastitis, $10 \mathrm{~mL}$ of milk was collected in sterile tubes. Before was made disinfection of teat orifice with cotton soaked in alcohol $70^{\circ} \mathrm{GL}$, identified for each mammary quarter and shipped immediately after collection, to the Regional Laboratory Diagnostics - Faculty of Veterinary (UFPel) under refrigeration in insulated containers with ice.

\section{Microbiology}

In the laboratory, samples were plated on blood agar (8\% defibrinated sheep blood), the reading of the plates held at 18 to $24 \mathrm{~h}$ in an oven maintained at a temperature of $36^{\circ} \mathrm{C}$ in aerobic atmosphere. The samples which were subjected to bacterial growth making smear stained by Gram and subsequently to the appropriate biochemical tests such as catalase, coagulase, and assimilation of carbohydrates for their identification.

All samples were biochemically characterized in the Bacteriology Sector of the Regional Diagnostic Laboratory of the Faculty of Veterinary Medicine. The methodology used to follow the Cowan and Steel bacterial identification manual (STEEL et al. 1993). The samples were subjected to the Catalase test to differentiate Staphylococcus spp. (positive catalase) from Streptococcus spp. and Enterococcus spp. (both negative catalase). Catalase positive samples were submitted to MR-VP (Methyl Red, VogesProskauer), Coagulase test and biochemical analyses against Ribose, Nitrate, Galactose, Maltose, Mannitol and Trealose, in addition to polymyxin resistance.

CAMP test was performed for catalase negative samples and Esculin, Inulin, Mannitol, Salicin, Sorbitol and Trealose tests. These samples were placed in BHI broth (Brain Heart Infusion), manufactured by Laboratórios Conda S.A. $+6.5 \% \mathrm{NaCl}$ to differentiate Streptococcus spp. (no growth) from Enterococcus spp. (there is growth). After carrying out the tests, the samples were placed in the oven at $37{ }^{\circ} \mathrm{C}$ and after $24 \mathrm{~h}$ the reading was done.

The study was conducted with frequency analysis of cases of clinical and subclinical mastitis and frequency of microorganisms observed. The total number of mammary quarters analysed was calculated the percentage of clinical mastitis, subclinical $(\mathrm{CMT}+++)$, non-infectious and infectious and the data were analysed descriptively.

\section{Results e Discussion}

In the four dairy farms studied, 94 (quarter mammary) cases of mastitis were observed, $82(87.2 \%)$ cases of subclinical mastitis $(\mathrm{CMT}+++)$ and $12(12.8 \%)$ cases of 
clinical mastitis. The bacterial isolation was observed in 62/94 (65.9\%) samples: 12 (19.4\%) originated from clinical mastitis and in 50 (80.6\%) from subclinical mastitis. Considering only subclinical mastitis $(n=82)$ bacterial isolation was 50, representing $60.8 \%$ (Table 1).

Table 1 - Distribution of clinical and subclinical mastitis frequency in four dairy farms in the city of Pelotas - RS

\begin{tabular}{lll}
\hline Mastitis & $\mathbf{N}$ & $\mathbf{\%}$ \\
\hline Clinical & 82 & $87.2 \%$ \\
Subclinical & 12 & 12.8 \\
\hline TOTAL & 94 & 100 \\
\hline
\end{tabular}

Zeryehun and Abera (2017) concluded that prevalence of mastitis particularly the subclinical mastitis was major problem of dairy cows when observed prevalence of clinical and subclinical mastitis and quarter level prevalence for clinical and subclinical mastitis were $12.5 \%$ and $51.8 \%$ at cow level. Clinically, 101 (6.6\%) quarters which belong to $75(19.5 \%)$ animals were found to be with blind teat.

Philpot and Nickerson (1991) indicate that $90 \%$ of mastitis are caused by bacteria. In addition to these pathogens, fungi, yeasts, algae, and viruses may also be involved in the etiology of the disease, but the occurrence is low. According to Ribeiro et al. (2003) infectious subclinical mastitis is one that presents positive test result for CMT, or other tests indicative and confirmed by microbial growth. This test was chosen because it is one of the most popular and practical tests for the diagnosis of subclinical mastitis, which analyzes separately the mammary glands of lactating cows (PHILPOT, 1994; DELLA LIBERA et al., 2011; PADUCH et al. 2013; GODDEN et al., 2017).

For some years, the frequency of clinical and subclinical mastitis in dairy cattle has been studied worldwide. It seeks to understand which microorganisms involved in each one to better understanding the origin and prevention of this disease. In relation to subclinical mastitis, like the results observed in this study, other authors did not have $100 \%$ of bacterial isolation in CMT positive milk samples. Costa et al. (1986) reported bacterial growth at $88.8 \%$ between $2533 \mathrm{CMT}$ positive milk samples, originating from 32 dairy properties, eighteen municipalities of the state of São Paulo- Brazil.

Results higher than those cited in this paper in relation to subclinical mastitis. 
Filippsen et al. (1999) showed that of 1.319 mammary quarters with CMT positive, 670 (50.0\%) presented in isolation microbiological, and Brito et al. (1999) analyzed samples 6315 , found that in $57.6 \%$ of bacteria were isolated. Beloti et al. (1997) working with 295 milk samples from subclinical mastitis, bacterial growth obtained in $223(75.6 \%)$ samples. These results are lower than those obtained in the present study. At the same time Costa et al. (1995) reported $46.5 \%$ positive mammary quarters the CMT showed bacterial isolation.

The different studies show frequency of mastitis in dairy farm, isolation frequency in subclinical and clinical mastitis and which microorganisms involved (KAKI et al., 2019; AMBROGGIO et al., 2018). Etiological agents may vary from place to place, depending on the weather; animal and livestock species and include a wide variety of gram-positive and gram-negative bacteria; fungal (DEB et al. 2013). Sargeant et al. (1998) describe the frequency of occurrence of clinical mastitis in dairy herds in Ontario. In 65 dairy farms involved in a 2-year observational study with 2840 cows and heifers, $19.8 \%$ of cows experienced one or more cases of clinical mastitis during lactation. Environmental, contagious, and minor pathogens were all associated with cases of clinical mastitis.

A study conducted by Ribeiro et al. (2001a) observed that the total of 9.079 with a positive reaction to CMT, $4.952(54.5 \%)$ showed microbial growth. Ribeiro et al. (2001b) showed that of 9.150 samples with positive CMT, $4.988(54.5 \%)$ had bacterial isolation. In another study Ribeiro et al. (2001c) found that of 1.554 samples positive to the CMT, 596 (38.4\%) presented microbial isolation. Confirming that not all milk samples positive present CMT bacterial growth. The same author notes that the greater the intensity of the reaction to CMT greater the number of samples positive microbiologically. This justifies the high percentage of this work insulations in cases of CMT positive, since it was only evaluated score +++ . To Brito et al. (1999), the number of bacterial isolates increased with the intensity of the reaction to CMT. Regarding 32 (34.1\%) samples with CMT +++ found in this study, which showed no bacterial isolation, can be explained by some physiological interferences. There are several factors that can influence the variation of SCC being cited: the order of birth, lactation, month and season (SCHEPERS et al., 1997; LAEVENS et al., 1997; SOUZA et al., 2005; CUNHA et al., 2008). For this reason, the CMT test should be performed as presumptive test for mastitis, just as it is necessary to repeat the microbiological examination in these cases. The inflammation may also be present without an infectious process in the gland, 
due to traumatic injuries, assaults by chemical agents, among other factors. The microbial agent may further have already been eliminated by the natural way of self-healing processes, resulting in a negative culture (RIBEIRO et al., 2003; BRITO et al., 1999; SKRZYPEK et al., 2004; GOMES et al., 2011).

Costa et al. (2001), in their study, 8.116 samples were collected from the mammary glands negative CMT, and $45.1 \%$ were isolated microorganisms contagious. Moreover, the test samples positive CMT not always show microbial growth. According to the author, it is suspected that the agent is not removed continuously false negative result may occur. According to Sears et al. (1993) and Brito et al. (1999), samples of milk should be confirmed microbiologically negative only after two or three analyzes.

Freitas et al. (2005) analyzed 984 quarters breast. Of these, 10 (1.0\%) had clinical mastitis and $562(57.1 \%)$ subclinical mastitis. Correlating the CMT test with microbiological examination, it was found that 562 of subclinical mastitis, only 356 (63.3\%) were positive for microbiological examination. The positive results in CMT, but negative in microbiological examination may indicate an inflammatory etiology of nonbacterial, because according to Costa et al. (1996), the CMT is a helper method in good correlation with the microbiological examination, however, the inflammatory process may not be of infectious origin.

The results reported for the identification of subclinical mastitis by CMT suggest greater caution in the use of this test as an indicator of intramammary infection by the finding of large numbers of milk samples without microbial growth, since it is probably a non-infectious subclinical mastitis. And we still need to work proactively in mastitis control, it is a disease management and to make a proper prevention, it is necessary to consider the entire property management, mainly including hygienic measures (CARVALHO et al., 2002, SILVA et al., 1998). These results are worrying, since according to Prado et al. (1997) the subclinical form is responsible for the largest losses in the production and composition of milk.

The quality of raw milk is influenced by multiple factors, among which are zootechnical factors associated with management, health of the mammary gland, feeding, genetic potential of the herds and factors related to the obtaining and storage of the milkmilk milk (GUERREIRO et al., 2005). One of the causes that exert extremely harmful influence on the composition and characteristics of milk is a mastitis (Müller, Ernst 2002).

In cases of clinical mastitis in $100 \%$ of cases was bacterial isolation, indicating that there is always the microbial involvement when the clinical signs are apparent. After 
the biochemical characterization identified: Negative Coagulase Staphylococcus spp. $(\mathrm{n}=29)$, Positive Coagulase Staphylococcus spp. $(\mathrm{n}=6)$, Corynebacterium spp. $(\mathrm{n}=16)$, Streptococcus spp. $(\mathrm{n}=7)$, Streptococcus uberis $(\mathrm{n}=4)$ (Table 1). The identification of the etiologic agent is important for the implementation of methods of prevention and control and monitoring of the herd. The importance of diagnosing subclinical mastitis and apparently healthy, the use of CMT, is to discover which animals can be transmitters of infection by line or by hand milking the milker (BRAMLEY et al., 1996; HARMON 1994). These animals besides being sources of contamination, contribute by low milk quality and lower total volume produced, which reflects in economic losses to property (MOEINI et al., 2002). However, despite the bacteriological diagnosis to be crucial, it is expensive and time consuming, not being applicable to herds with large numbers of animals. Several simplifications have been studied in order to eliminate these difficulties, the use of special culture media and creating schemes presumptive identification (RIBEIRO et al., 2003; FIGUEIREDO, 1995).

\begin{tabular}{lcc} 
Table 2- Microrganisms isolated from milk of cows with mastitis in Pelotas - Rio Grande do Sul \\
\cline { 2 - 3 } \multicolumn{1}{c}{ Microrganisms } & $\mathrm{N}$ & $\%$ \\
\hline Coagulase negative Staphylococcus spp. & 29 & 46,8 \\
Coagulase positive Staphylococcus spp. & 6 & 9,7 \\
Corynebacterium spp. & 16 & 25,8 \\
Streptococcus spp. & 7 & 11,3 \\
Streptococcus uberis & 4 & 6,4 \\
\hline TOTAL & 62 & 100 \\
\hline
\end{tabular}

The species isolated in this study belonged to the classification of major pathogens (53.2\%) and minor (46.8\%), environmental (11.3\%) and infectious $(88.7 \%)$ and primary $(27.4 \%)$ and secondary (72.6\%). The most common microorganisms in cases of bovine mastitis are Staphylococcus aureus, Staphylococcus spp., Streptococcus dysgalactiae, Streptococcus uberis, Corynebacterium spp., Escherichia coli, Nocardia spp. Prototheca and zopffi (BRABES et al., 1999; BIRHANU et al., 2017; SULEIMAN et al., 2018; ROCHA et al., 2019; BIANCHI et al., 2019; NAUSHAD et al., 2019).

Among the contagious pathogens, Staphylococcus aureus is the most frequent and prevalent in cases of bovine mastitis. It causes clinical and subclinical intramammary infection with serious economic loss and herd management problems in dairy cows 
(ZSCHÖCK et al., 2000; Kerro Dego et al., 2002). According Gentilini et al. (2002) currently CN Staphylococcus have received greater importance as causative agents of intramammary infections in dairy cattle worldwide (KROL et al., 2016; RASPANTI et al., 2016; HOEKSTRA et al., 2018; MAHMMOD et al., 2018; RONCO et al., 2018; MACFADYEN et al., 2019). The $S$. aureus is known worldwide as a causative agent of various purulent diseases in both humans and animals (BEAN; GRIFFIN, 1990) is also one of the most important causes of food poisoning (PENNA et al., 1998) due to production of various enterotoxins (OMOE et al., 2002). Thus, the milk and dairy products are important vehicles of S. aureus and are commonly involved in outbreaks of food poisoning (BERGDOLL, 1989).

Although most articles reviewing belong to Brazilian studies in other countries, such as Sweden, the isolated species are the same: The most common isolates of 590 bacteriological diagnoses were Staphylococcus aureus (19\%) and NC Staphylococcus sp. (NCS 16\%) followed by S. dysgalactiae (9\%), S. uberis (8\%), Escherichia coli (2.9\%), and Streptococcus spp. (1.9\%) (PERSSON et al., 2012). The distribution of the most commonly isolated bacteria considering only bacteriological positive samples were: $S$. aureus (31\%), NC Staphylococcus spp. (27\%), S. dysgalactiae (15\%), S. uberis (14\%), E. coli $(4.8 \%)$, and Streptococcus spp. (3.1\%).

The correct identification of $S$. aureus from bovine mastitis is important both from the epidemiological point of view as the prevention of infections, including immunoprophylaxis (BRITO et al., 2002; SOUZA et al., 2019). In Pernambuco, Pinheiro de Sá et al. (2000) found that the most common microorganisms in cases of bovine mastitis were Staphylococcus spp. (32.6\%) and Corynebacterium spp. (13.2\%), but among Staphylococcus isolated, the species $S$. aureus was the most prevalent (66.4\%).

In 2001, a nationwide survey was conducted in Finland to estimate prevalence of bovine mastitis, distribution of mastitis pathogens. The results were compared with those of a previous survey done in 1995 . The prevalence of mastitis continued to decrease from $38 \%$ in 1995 to $31 \%$ in 2001 . This mainly resulted from increased prevalence of Corynebacterium bovis. NC Staphylococcus spp. remained the most common bacterial group, comprising almost one-half of the pathogens isolated, whereas the relative number of Staphylococcus aureus isolations decreased from the time of the previous study. Compared with the other Nordic countries, penicillin resistance among the Staphylococcus spp. was still at a relatively high level in Finland (52.1 and 32.0\% for Staphylococcus aureus and CN Staphylococcus, respectively) (PIKALA et al., 2001). 
Mastitis causing CN Staphylococcus and Staphylococcus aureus are compared to Taponen; Pyörälä (2008). Staphylococcus spp. are the bacteria most commonly isolated from bovine mastitis, and CNS are now predominant over S. aureus in most countries. CNS include various species, but only a few prevail in bovine mastitis. S. aureus can cause clinical mastitis, but often causes subclinical mastitis, which remains persistent and increases milk somatic cell count. CNS, traditionally regarded as minor pathogens, seem to lack the ability to cause severe mastitis. CNS can, however, persist in the mammary gland and moderately increase milk somatic cell count.

Freitas et al. (2005) noted that the most prevalent agents in bovine mastitis in Pernambuco (Brazil) were 36\% NC Staphylococcus spp., Corynebacterium spp. 34.8\% and $S$. aureus $13.6 \%$.

Besides the problems with the infected animals, the study of microorganisms in milk also reveals knowledge about its index of microbial contamination that can be used in the prosecution of its intrinsic quality and sanitary conditions of its production and herd health. Considering the potential to multiply the bacteria in the milk can cause chemical changes such as degradation of fats, proteins or carbohydrates, which may render the product unfit for consumption and industrialization (COUSIN, 1982).

It has questioned the interpretation of the CMT as diagnosing subclinical mastitis, being a subjective test with false-positive or false-negative (MARTIN et al., 1994; CASURA et al., 1995). However, even with some positive results in CMT, but that does not indicate an infectious process, the articles reviewed indicate that this test should be routinely performed for measures in the handling of animals and milking line are adopted to ensure maximum production and quality of milk (BARBOSA et al., 2002; OLIVEIRA et al., 2011).

\section{Conclusion}

Based on the research about clinical and subclinical mastitis, microorganisms more frequent and prevalent in mastitis cases, and similarity between positive CMT and isolations of bacterial, these results were able to visualize, in the region of Pelotas - RS, a frequency of clinical and subclinical mastitis in four dairy properties in the period of six months similar results also observed in the country and in the world. It was also possible to know the microorganisms involved in these two cases and confirm what has been happening in research from other locations. Besides, the results reinforce the importance of prevention and control of this disease. 


\section{References}

ADKINS, P.R.F.; MIDDLETON, J.R. Methods for Diagnosing Mastitis. Vet. Clin. North Am. Food Anim. Pract., v. 34(3), p. 479-491, 2018.

AMBROGGIO, M. B.; PERRIG, M. S.; CAMUSSONE, C.; et al. Survey of potential factors involved in the low frequency of CP5 and CP8 expression in Staphylococcus aureus isolates from mastitis of dairy cattle from Argentina, Chile, and Uruguay. J. Appl. Genet., v. 59(3), p.357-363, 2018.

BARBOSA, C. P.; BENEDETTI, E.; RIBEIRO, S. C.A.; GUIMARÃES, E. C. Relação entre contagem de células somáticas (CCS) e os resultados do "California Mastitis Test" (CMT) no diagnóstico de mastite bovina. Bioscience Journal, v. 18(1), p. 93-102, 2002.

BEAN, N. H.; GRIFFIN, P. M. Foodborne disease outbreaks in the United States, 19731987: pathogens, vehicles, and trends. Journal of Food Protection, v. 53(9), p. 804817, 1990.

BELOTI, V., MÜLLER, E. E.; FREITAS, J. C.; METTIFOGO, E. Estudo da mastite subclínica em rebanhos leiteiros no norte do Paraná. Seminario Ciências Agrárias, v. 18(1), p. 45-53, 1997.

BERGDOLL, M. S. Staphylococcus aureus. In: Doyle MP (Ed.). Foodborne bacterial pathogens. New York, Marcell Dekker, 1989, p. 463-523.

BIANCHI, R.M.; SCHWERTZ, C.I.; de CECCO, B.S. et al. Pathological and microbiological characterization of mastitis in dairy cows. Trop Anim Health Prod. v. 51(7), p.2057-2066, 2019.

BIRHANU, M.; LETA, S.; MAMO, G.; TESFAYE, S. Prevalence of bovine subclinical mastitis and isolation of its major causes in Bishoftu Town, Ethiopia. BMC Res Notes, v. 10(1), p.767, 2017.

BRABES, K. C. S.; CARVALHO, E. P.; DIONÍSIO, F. L.; PEREIRA, M. L.;

GARINO, F.; COSTA, E. O. Participação de espécies coagulase positivas e negativas produtoras de enterotoxinas do gênero Staphylococcus na etiologia de casos de mastite bovina em propriedades de produção leiteira dos Estados de São Paulo e Minas Gerais. Revista Napgama, v. 2(3), p. 4-11, 1999.

BRAMLEY, A. J.; CULLOR, J. S.; ERSKINE, R. J.; FOX, L. K.; HARMON, R. J.; HOGAN, J. S.; NICKERSON, S. C.; OLIVER, S. P.; SMITH, K. L.; SORDILLO, L. M. Current of Bovine Mastitis. 4th ed. Madison: National Mastitis Council. 1996, p. 64.

BRITO, M. A. V. P.; BRITO, J. R. F.; PORTUGAL, J. A. B. Identificação de contaminantes bacterianos no leite cru de tanques de refrigeração. Rev. Inst. Lat. Când. Tostes, v. 57, p. 47-52, 2002. 
BRITO, M. A. V. P.; BRITO, J. R. F.; RIBEIRO, M. T.; VEIGA, V. M. O. Padrão de infecção intramamária em rebanhos leiteiros: exame de todos os quartos mamários das vacas em lactação. Arquivo Brasileiro de Medicina Veterinária e Zootecnia, v. 51(2), p. 33-35, 1999.

CARVALHO, L. A.; NOVAES, L. P.; MARTINS, C. E.; ZOCCAL, R.; MOREIRA, P.; RIBEIRO, A. C. C. L.; LIMA, V. M. B. 2002. Embrapa Gado de Leite Sistema de Produção 2 In:

http://sistemasdeproducao.cnptia.embrapa.br/FontesHTML/Leite/LeiteCerrado/manejo/ ma mite.html Acessed in 2 September 2007.

CASURA, C.; SCHUKKEN, Y.H.; RÜSCH, P. Quality assessment of California mastitis test as a diagnostic tool in quarter somatic cell count estimation, Proc. IDF Int. Mastitis Seminar, v. 3, p. 57-58, 1995.

COSTA, E. O. Importância da mastite na produção leiteira do Brasil. Revista de Educação Continuada do CRMV-S,. v. 1, p. 3-9, 1998.

COSTA, E. O.; CARCIOFI, A. C.; MELVILLE, P. A.; PRADA, M. S.; SCHALCH, U. Estudo etiológico da mastite clínica bovina. Revista Brasileira de Medicina Veterinária, v.17, p. 156-159, 1995.

COSTA, E. O.; COUTINHO, S. D.; TEIXEIRA, C. M. Etiologia bacteriana da mastite bovina no estado de São Paulo, Brasil. Revista Microbiológica. v. 17(2), p. 107-112, 1986.

COSTA, E. O.; MELVILLE, P. A.; RIBEIRO, A. R.; WATANABE, E. T.; CARCIOFI, A. C.; PORADA, M. S. Desinfecção mamária pós-ordenha: avaliação de sua eficiência no controle de mastite bovina. In: Anais Congresso Brasileiro de Medicina Veterinária 24. Goiânia, GO. 1996.

COSTA, E. O.; RIBEIRO, A. R.; GARINO, Jr. F.; SILVA, J. A. B.; WATANABE, E. T.; DELIBRE, E.; LEÃO, E. F. Portador: um importante elo na epidemiologia de mastite infecciosa bovina. In: Anais Congresso Brasileiro de Medicina Veterinária 28 2001, Salvador, 2001.

COUSIN, M. A. Presence, and activity psychotropic microorganisms in milk and dairy products. Journal of Food Protection, v. 45, p. 172, 1982.

CUNHA, R. P. L.; MOLINA, L. R.; CARVALHO, A. V.; FACURY FILHO, E. J.; FERREIRA, P. M.; GENTILINI, M. B. Mastite subclínica e relação da contagem de células somáticas com número e lactações, produção e composição química do leite em vacas da raça Holandesa. Arq Bras Med Vet Zootec, v. 60, p.19-24, 2008.

DEB, R.; KUMAR, A.; CHAKRABORTY, S.; et al. Trends in diagnosis and control of bovine mastitis: a review. Pak. J. Biol. Sci., v. 16(23), p. 1653-1661, 2013.

DELLA LIBERA, A. M. M. P.; SOUZA, F. N.; BLAGITZ, M. G.; BATISTA, C. F. Avaliação de indicadores inflamatórios no diagnóstico da mastite bovina. Arquivos do 
Instituto Biológico, v. 78(2), p. 297 300, 2011.

DETILLEUX, J. Tolerance to bovine clinical mastitis: Total, direct, and indirect milk losses. Journal of Dairy Science v.101(4), p.3334-3343, 2018.

FIGUEIREDO, J. B. Mamite bovina: visão panorâmica de uma doença complexa In: Anais Congresso Brasileiro de Reprodução Animal 11 Belo Horizonte. Anais...:176, 1995.

FILIPPSEN, L. F. Prevalência da mastite bovina causada por Prototheca zopfii em rebanhos leiteiros, na região Norte do Paraná. Ciência Rural, v. 29(1), p. 87-89, 1999.

FONSECA, L. F. L.; SANTOS, M. V. Qualidade do Leite e Controle de Mastite. São Paulo: Lemos Editorial, 2000. 175p.

FREITAS, M. F. L.; PINHEIRO JÚNIOR, J. W.; STAMFORD, T. L. M,; RABELO, S. S. A.; SILVA, D. R.; SILVEIRA, V. M.; SANTOS, F. G. B.; SENA, M. J.; MOTA, R. A. Perfil de sensibilidade antimicrobiana in vitro de Staphylococcus coagulase positivos isolados de leite de vacas com mastite no agreste do estado de Pernambuco. Arq. Inst. Biol., v. 72(2), p. 171-177, 2005.

GENTILINI, E.; DENAMIEL, G.; BETANCOR, A. Antimicrobial susceptibility of Coagulase-Negative Staphylococci isolated from bovine mastitis in Argentina. Journal of Dairy Science, v. 85, p.1913-1917, 2002.

GODDEN, S.M.; ROYSTER, E.; TIMMERMAN, J.; RAPNICKI, P.; GREEN, H. Evaluation of an automated milk leukocyte differential test and the California Mastitis Test for detecting intramammary infection in early- and late-lactation quarters and cows. Journal of Dairy Science v.100(8), p.6527-6544, 2017.

GODKIN, M. A.; LESLIE, K. E. Culture of bulk tank milk as a mastitis screening test: a brief review. Canadian Veterinary Journal, v. 34, p. 601-605, 1993.

GOMES, V.; MADUREIRA, K. M.; DELLA LIBERA, A. M. M. P.; BLAGITZ, M. G.; ALVES, M.; BAPTISTELLA, F.; BENESI, F. J. Dinâmica da celularidade do colostro de vacas da raça Holandesa no pós-parto imediato. Arq. Bras. Med. Vet. Zootec., v. 63(5), p. 1047-1053, 2011.

GUERREIRO, P. K.; MACHADO, M. R. F.; BRAGA, G. C.; GASPARINO, E.; FRANZENER, A. S. M. Milk microbiological quality according to prophylactic techniques in production management. Agrotech. Sci., v. 29, p. 216-222, 2005.

GUIMARÃES, F. F.; LANGONI, H. Leite: Alimento imprescindível, mas com riscos para saúde pública. Vet. e Zootec., v. 16(1), p. 38-51, 2009.

HARMON, R. J. Physiology of mastitis and factors affecting somatic cell counts. J. Dairy Research, v. 77, p. 2103-2112, 1994.

HARMON, R. J. Somatic cell counts: a primer. In: Annual Meeting National Mastitis Council 40. Reno. Anais... Madison: National Mastitis Council: 3-9, 2001. 
HEIKKILÄ, A.M.; LISKI, E.; PYÖRÄLÄ, S.; TAPONEN, S. Pathogen-specific production losses in bovine mastitis. Journal Dairy Science v. 101(10), p. 9493-9504, 2018.

HERINGSTAD, B.; KLEMETSDAL, G.; RUANE, J. Clinical Mastitis in Norwegian Cattle: Frequency, Variance Components, and Genetic Correlation with Protein Yield. Journal Dairy Science v. 82, p. 1325-1330, 1999.

HOEKSTRA, J.; RUTTEN, V.; SOMMELING, L. et al. High Production of LukMF' in Staphylococcus aureus Field Strains Is Associated with Clinical Bovine Mastitis. Toxins (Basel). v.10(5), p.200, 2018.

JAN, M.; SARGEANT, H.; MORGAN, S.; KEN, E.; LESLIE, M. J.; IRELAND, A. B. Clinical mastitis in dairy cattle in Ontario: Frequency of occurrence and bacteriological isolates. Can. Vet. J., v. 39, p. 33-38, 1998.

KAKI, A. A.; DJEBALA, S.; LATIF, M. B.; MOULA, N. Evaluation of the Prevalence of Subclinical Mastitis in Dairy Cattle in the Soummam Valley (Bejaia, Algeria).

Bulletin UASVM Veterinary Medicine, v. 76(2), 2019.

KERRO DEGO, O.; VAN DIJK, J.E.; NEDERBRAGT, H. Factors involved in the early pathogenesis of bovine Staphylococcus aureus mastitis with emphasis on bacterial adhesion and invasion. A review. Vet Q. v.24(4), p.181-198, 2002.

KHAN I.T.; NADEEM, M.; IMRAN, M.; ULLAH, R.; AJMAL, M.; JASPAL, M.H. Antioxidant properties of Milk and dairy products: a comprehensive review of the current knowledge. Lipids Health Dis. V.18(1), p.41, 2019.

LAEVENS, H.; DELUYKER, H.; SCHUKKEN, Y. H.; De MEULEMEESTER, L.; VANDERMEERSCH, R.; DE MUÃĒLENAERE, E.; DE KRUIF, A. Influence of parity and stage of lactation on the somatic cell count in bacteriologically negative dairy cows. Journal Dairy Science, v. 80, p. 3219-3226, 1997.

MACFADYEN, A.C.; LEROY, S.; HARRISON, E.M.; PARKHILL, J.; HOLMES, M.A.; PATERSON, G.K. Staphylococcus pseudoxylosus sp. nov., isolated from bovine mastitis. Int J Syst Evol Microbiol. v,69(8), p,2208-2213, 2019.

MACHADO, P. F.; PEREIRA, A. R.; SILVA, L. F. P. Células somáticas no leite em rebanhos brasileiros. Scientia Agricula, v. 57(2), p. 359- 361, 2000.

MAHMMOD YS, TOFT N, KATHOLM J, GRØNBÆK C, KLAAS IC. Bayesian estimation of test characteristics of real-time PCR, bacteriological culture and California mastitis test for diagnosis of intramammary infections with Staphylococcus aureus in dairy cattle at routine milk recordings. Prev Vet Med. v.112(3-4), p.309-317, 2013.

MARTIN, S. W.; MEEK, A. H.; WILLEBERG, P. Measurement of disease frequency and production, In: Martin S. W., Meek A. H. \& Willeberg P. (ed.) Veterinary

Epidemiology. Principles and Methods. Iowa State University Press, Ames. 1994. p. 48-76. 
MARTINS, P. F.; ANDRADE, H. V. Identificação de Resíduos de Antibióticos na Recepção de Leite Cru Pré-Beneficiado Como Implantação do Plano APPCC em Laticínios. FAZU em Revista, v. 8, p. 108-114, 2011.

MENDONÇA, C. L.; FIORAVANT, M. C. S.; SILVA, J. A. Etiologia da mastite bovina. Veterinária Notícias, v. 5(1), p.107-118, 1999.

METZGER, S.A.; HERNANDEZ, L.L.; SUEN, G.; RUEGG, P.L. Understanding the Milk Microbiota. Vet Clin North Am Food Anim Pract. v. 34(3), p.427-438, 2018.

MIRA, S. C.; DELLA LIBERA, A. M. P.; SOUZA, N. F.; LIMA, S. M.; BLAGITZ, G. M. Celularidade do leite no diagnóstico de infecções intramamárias em bovinos. Rev. Cienc. Agrar. v. 56(1), p.7-11, 2013.

MOEINI, M. M.; SANJABI, M. R.; AHADI, A. H. High bacteria count in milk and it's economic loss. In: World Buiatrics Congress 22. Hannover. Anais...: 9-10, 2002.

NAUSHAD, S.; KANEVETS, U.; NOBREGA, D. et al. Staphylococcus debuckii sp. nov., a coagulase-negative species from bovine milk. Int J Syst Evol Microbiol. v. 69(8), p. 2239-2249, 2019.

OLIVEIRA, C. M. C.; SOUSA, M. G. S.; SILVA, N. S.; MENDONÇA, C. L.; SILVEIRA, J. A. S.; OAIGEN, R. P.; ANDRADE, S. J. T.; BARBOSA, J. D.

Prevalência e etiologia da mastite bovina na bacia leiteira de Rondon do Pará, estado do Pará. Pesq. Vet. Bras., v. 31(2), p.104-110, 2011.

OMOE, K.; ISHIKAWA, M.; SHIMODA, Y.; HU, D.; UEDA, S.; SHINAGAWA, K. Detection of seg, she, and sei genes in Staphylococcus aureus isolates and determination of the enterotoxin productivities of Staphylococcus aureus isolates harborin seg, seh, or sei genes. J. Clin. Microbiol., v. 40 (3), p. 857-862, 2002.

ORTEGA-ANAYA, J.; JIMÉNEZ-FLORES, R. Symposium review: The relevance of bovine milk phospholipids in human nutrition-Evidence of the effect on infant gut and brain development. J Dairy Sci. v.102(3), p.2738-2748, 2019.

PADUCH, J.H.; HEROLD, M.; KRÖMKER, V. Diagnostische Eigenschaften eines neuen California-Mastitis-Tests [Diagnostic characteristics of a new California Mastitis Test]. Tierarztl Prax Ausg G Grosstiere Nutztiere. v.41(2), n.81-87, 2013.

PANG, M.; XIE, X.; BAO, H. et al. Insights Into the Bovine Milk Microbiota in Dairy Farms With Different Incidence Rates of Subclinical Mastitis. Front Microbiol. v.9, p.2379, 2018.

PENNA, T. C. V.; COLOMBO, A. J.; ABE L. E. M.; ACHOSHVILI, S. A. M. Parâmetros de resistência térmica de cepas de Staphylococcus aureus enterotoxigênicos no leite. Rev. Farm. Bioq. v. 24, p. 113-117. 1998.

PERSSON, Y.; NYMAN, A. K.; GRÖNLUND-ANDERSSON, U. Etiology and antimicrobial susceptibility of udder pathogens from cases of subclinical mastitis in 
dairy cows in Sweden. PLoS One. v. 7(10), 2012.

PHILPOT, W. N. Dairy herd management practices for improving milk quality and controlling mastitis. In: Dairy Research Report. Lousiana State University, 1994. p.1325.

PHILPOT, W. N.; NICKERSON, S. C. Mastitis: Counter Attack. A strategy to combat mastitis. Ilinois: Badson Brothers Co., 1991. p.150.

PIKALA, M.; HAVERI, S.; PYÖRÄLÄ, V.; MYLLYS, T.; HONKANEN-BUZALSKI. Bovine mastitis in Finland 2001 prevalence, distribution of bacteria, and antimicrobial resistance. Vet. Microbiol., v. 16 (1-2), p. 29-36. 2009.

PINHEIRO DE SÁ, M. E.; MOTA, R. A.; SOUZA, M. I.; OLIVEIRA, A. A. F. Etiologia da mastite subclínica em bovinos leiteiros do agreste meridional do Estado de Pernambuco. Rev. Bras. Ciênc. Veter., v. 7(2), p. 100-1003, 2000.

PRADO, E.; CRUZ, F. E. R.; VIANA, F. C. Problemas sanitários do rebanho de leite: percepção dos criadores. Arq. Bras. Med. Vet. Zoot., v. 49(1), p. 19-29. 1997.

PUGGIONI, G.M.G.; TEDDE, V.; UZZAU, S. et al. Evaluation of a bovine cathelicidin ELISA for detecting mastitis in the dairy buffalo: Comparison with milk somatic cell count and bacteriological culture. Res Vet Sci. v.128, p.129-134, 2020.

RADOSTITIS, O. M.; LESLIE, K. E.; FETROW, J. Mastitis control in dairy herds. In: Radostitis OM, LESLIE KE, FETROW J. Herd health food animal production medicine. Philadelphia: WB Saunders. 1994. p. 229-276.

RAMALHO, C. A.; SOARES, K. D. A.; SILVA, D. F.; BARROS, M. R. C.; JUNIOR, J. W. P.; OLIVEIRA, J. M.; MOTA, R. A.; MEDEIROS, E. S. Eficácia in vitro de desinfetantes comerciais utilizados no pré e pós-dipping frente a Staphylococcus spp. isolados em rebanhos leiteiros. Pesq. Vet. Bras., v. 32(12), p.1285- 1288, 2012.

RIBEIRO, M. E. R.; STUMPF, Jr. W.; GOMES, J. F., et al. Mastite causada por Staphylococcus coagulase negativa em um rebanho Jersey na região de clima temperado In: Congresso Brasileiro de Medicina Veterinária 28. Salvador. SBMV Anais...: 162. 2001c.

RIBEIRO, M. E. R.; STUMPF, Jr. W.; GOMES, J. F., et al. Ocorrência de Streptococcus sp. em Unidades de Produção Leiteiras monitoradas na região sul do Rio Grande do Sul. In: Congresso Brasileiro de Medicina Veterinária 28. Salvador. SBMV Anais...: 162. 2001b.

RIBEIRO, M. E. R.; STUMPF, Jr. W.; GOMES, J. F., et al.. Relação de CMT positivo e crescimento microbiológico no diagnóstico da mastite bovina na região sul do Rio Grande do Sul. In: Congresso Brasileiro de Zootecnia 21. Congresso Internacional de Zootecnia 3. Goiânia. SBZ. Anais...: 98, 2001ª .

RIBEIRO, M. E.; PETRINI, L. A.; AITA, M. F.; BALBINOTTI, M.; STUMPF, Jr. W.; GOMES, J. F.; SCHRAMM, R. C.; MARTINS, P. R.; BARBOSA, R. S. Relação entre mastite clínica, subclínica infecciosa e não infecciosa em unidades de produção leiteiras 
na região sul do Rio Grande do Sul. Rev. Bras. Agroc. v. 9(3), p. 287-290, 2003.

ROCHA, L.S.; SILVA, D.M.; SILVA, M.P. et al. Comparative genomics of Staphylococcus aureus associated with subclinical and clinical bovine mastitis. PLoS One. v.14(8):e0220804. 2019.

RONCO, T.; KLAAS, I.C.; STEGGER, M. et al. Genomic investigation of Staphylococcus aureus isolates from bulk tank milk and dairy cows with clinical mastitis. Vet Microbiol. v.215, p.35-42, 2018.

RUPP, R.; BEAUDEAU, F.; BOICHARD, D. Relationship between milk somatic-cell counts in the first lactation and clinical mastitis occurrence in the second lactation of French Holstein cows. Prev. Vet. Med., v. 46, p.99-111, 2000.

SCHEPERS, A. J.; LAM, T. J. G. M.; SCHUKKEN, Y. H.; WILMINK, J. B. M.; HANEKAMP, W. J. A. Estimation of variance components for somatic cell counts to determine thresholds for uninfected quarters. J. Dairy Sci., v. 80, p. 1833-1840, 1997.

SEARS, P. M.; GONZALÈZ, R. N.; WILSON, D. J.; HAN, H. R. Procedures for mastitis diagnosis and control. Veterinary Clinics of North America: Food Animal Practice, v. 9(3), p. 445-468, 1993.

SILVA, N.; LOBATO, F. C. F.; COSTA, G. M. Mastitis aguda espontânea por Klebsiella en bovinos Holstein. In: Panamerican Congress on Mastitis Control and Milk Quality, Mérida, México. 1998. p. 144-147.

SKRZYPEK, R.; WÓJTOWSKI, J.; FAHR, R. D. Factors affecting somatic cell count in cow bulk tank milk - A case study from Poland. Journal of Veterinary Medicine Series A v. 51(1), p. 127-131, 2004.

SOUZA, G. N.; BRITO, J. R. F.; MOREIRA, E. C.; BRITO, M. A. V. P.; SILVA, M. V. G. B. Fatores de risco para alta contagem de células somáticas do leite do tanque em rebanhos leiteiros da Zona da Mata de Minas Gerais, Brasil. Arq. Bras. Med. Vet. Zootec., v. 57(2), p.251-260, 2005.

SOUZA, G. N.; MOREIRA, E. C.; BRITO, J. R. F.; BRITO, M. A. V. P.; SILVA, M. V. G. B. Variação da contagem de células somáticas em vacas leiteiras de acordo com patógenos da mastite. Arq. Bras. Med. Vet. Zootec., v. 61(5), p. 1015-1020, 2009.

SOUZA, G.Á.A.D.; DE ALMEIDA, A.C.; XAVIER, M.A.S. et al. Characterization and molecular epidemiology of Staphylococcus aureus strains resistant to beta-lactams isolated from the milk of cows diagnosed with subclinical mastitis. Vet World. v,12(12), p.1931-1939, 2019.

STEEL, Kenneth John; BARROW, G. I.; FELTHAM, R. K. A. Cowan and Steel's manual for the identification of medical bacteria. Cambridge university press, 1993.

SULEIMAN, T.S.; KARIMURIBO, E.D.; MDEGELA, R.H. Prevalence of bovine subclinical mastitis and antibiotic susceptibility patterns of major mastitis pathogens isolated in Unguja island of Zanzibar, Tanzania. Trop Anim Health Prod. v.50(2), p.259-266, 2018. 
TAPONEN, S.; PYÖRÄLÄ, S. Coagulase Negative Staphylococci as cause of bovine mastitis- not so different from Staphylococcus aureus. Acta Vet. Scand., v. 8, p.53-36, 2011.

WOLLOWSKI, L.; BERTULAT, S.; KOSSATZ, A.; HEUWIESER W. Short communication: Diagnosis and classification of clinical and subclinical mastitis utilizing a dynamometer and a handheld infrared thermometer. Journal Dairy Science. v. 102(7), p. 6532-6539, 2019.

ZERYEHUN, T., ABERA, G. Prevalence and Bacterial Isolates of Mastitis in Dairy Farms in Selected Districts of Eastern Harrarghe Zone, Eastern Ethiopia. J Vet Med. v. 2017, p. 6498618, 2017.

ZSCHÖCK, M.; BOTZLER, D.; BLÖCHER, S.; SOMMERHÄUSEN, J.; HAMANN, H. P. Detection of genes for enterotoxins (ent) and toxic shock syndrome toxin-1 (tst) in mammary isolates of Staphylococcus aureus by polymerase-chain-reaction. Int. Dairy J., v. 10, p. 569-574, 2000. 